\title{
PHYSICAL AND PHYSIOLOGICAL ATTRIBUTES OF SAVED COWPEA SEEDS USED IN THE BRAZILIAN SEMI-ARID REGION ${ }^{1}$
}

\author{
FERNANDO HENRIQUE ALVES DA SILVA ${ }^{2 *}$, SALVADOR BARROS TORRES ${ }^{2}$, SARA MONALIZA COSTA \\ CARVALHO ${ }^{2}$, MANUELA BAI ${ }^{3}$, WELDER DE ARAÚJO RANGEL LOPES ${ }^{2}$
}

\begin{abstract}
This study evaluated the physical and physiological attributes of saved cowpea seeds (Vigna unguiculata L. Walp.) used in the Brazilian semi-arid area and compared them with certified seed varieties. The study tested 37 saved seed samples from the state of Rio Grande do Norte and two varieties of certified seeds ("BRS Guariba" and "BRS Pujante") from the production field of Embrapa Products and Market, Petrolina, PE, Brazil. The seeds were tested for moisture, hectoliter weight, weight of 1,000 seeds, and physical purity to evaluate the physical quality. Germination, first germination count, field emergence, emergence rate index, shoot dry mass, and accelerated aging were tested for physiological quality. The saved cowpea seeds showed great differences, suggesting the influence of genetic variability and different growing environments. The use of saved cowpea seeds by small farmers in the semi-arid areas of Northeastern Brazil is impractical, because these seeds have inferior physical and physiological qualities compared to certified cowpea seeds.
\end{abstract}

Keywords: Vigna unguiculata. Physical quality. Certified seed. Physiological potential.

\section{ATRIBUTOS FÍSICOS E FISIOLÓGICOS DE SEMENTES SALVAS DE FEIJÃO-CAUPI UTILIZADAS NO SEMIÁRIDO BRASILEIRO}

RESUMO - Objetivou-se avaliar a qualidade física e fisiológica de sementes salvas de feijão-caupi (Vigna unguiculata L. Walp.) utilizadas no semiárido brasileiro e compará-las com as variedades de sementes certificadas. Foram testadas 37 amostras de sementes salvas oriundas de diferentes municípios do Rio Grande do Norte e duas variedades de sementes certificadas (BRS Guariba e BRS Pujante), provenientes do campo de produção da Embrapa Produtos e Mercado, Petrolina, PE. Para avaliação da qualidade física, as sementes foram submetidas aos testes de grau de umidade, peso hectolítrico, peso de mil sementes e pureza física. Na avaliação da qualidade fisiológica testou-se a germinação, primeira contagem de germinação, emergência em campo, índice de velocidade de emergência, matéria seca de parte aérea e envelhecimento acelerado. As sementes salvas de feijão-caupi apresentaram grandes diferenças, sugerindo tanto a influência da variabilidade genética como dos diferentes ambientes de cultivo. A utilização de sementes salvas de feijão-caupi pelos pequenos produtores das áreas semiáridas do nordeste do Brasil se constitui em prática inviável por se tratar de sementes de qualidades física e fisiológica inferiores às sementes de origem certificadas.

Palavras-chaves: Vigna unguiculata. Qualidade física. Semente certificada. Potencial fisiológico.

\footnotetext{
${ }^{*}$ Corresponding author

${ }^{1}$ Received for publication in $11 / 22 / 2017$; accepted in $03 / 21 / 2018$.

Paper extracted from the Master's dissertation of the first author.

${ }^{2}$ Agricultural Sciences Center, Universidade Federal Rural do Semi-Árido, Mossoró, RN, Brazil; fernandosilvasr@hotmail.com - ORCID: 0000-0001-7752-1881, sbtorres@ufersa.edu.br - ORCID: 0000-0003-0668-3327, saramonaliza@ufersa.edu.br - ORCID: 0000-0001-85563862, welder.lopes@hotmail.com - ORCID: 0000-0002-9380-6710.

${ }^{3}$ Faculty of Agriculture /rural development, Universidade São Tomás de Moçambique, Maputo, Mozambique; manuela.baai@gmail.com ORCID: 0000-0002-8437-3968.
} 


\section{INTRODUCTION}

The cowpea (Vigna unguiculata L. Walp.) is a main component of the basic diet of the low-income population and one of the most important legumes in the tropical and subtropical regions worldwide. Currently, Brazil is the third largest producer of cowpea, which is grown mainly in the North $(55,800$ ha) and Northeast (1.2 million ha) (SANTOS et al., 2014). In the latter region, this species is considered an important generator of employment and income for rural producers (BERTINI et al., 2010). Despite Brazil's high production, supply shortages are frequent in some regions of the country. This is due to the low average yield in some Brazilian regions, which does not exceed $300 \mathrm{~kg} / \mathrm{ha}$ (LEITE et al., 2009). The low production is also probably due to the use of saved seeds that fail to meet established standards, leading to failure during germination and delayed emergence of seedlings (LOBO JÚNIOR et al., 2013). Another important factor is the poor sanitary quality of these seeds. The high frequency and incidence of pests and diseases depreciate commercialization and impair sowing (DUTRA et al., 2016).

The physical and physiological attributes of a given batch of seeds can be verified by several tests following norms established and standardized in the Rules for Seed Analysis (BRASIL, 2009). These criteria are necessary for legal activity in the field of seed technology (LOBO JÚNIOR et al., 2013). In Brazil, these criteria are determined and inspected by the Ministry of Livestock and Supply (MAPA).

The main tests to evaluate physical attributes of seeds are physical purity, moisture, hectoliter weight, appearance, and weight of 1,000 seeds. The tests to evaluate physiological quality seek to determine specific activities whose manifestations depend on the vigor (MARCOS-FILHO; NOVEMBRE, 2009). The germination test conducted under optimal environmental conditions is one of them, and it expresses the maximum potential of germinated seeds (BRASIL, 2009). However, this test in isolation often does not inform the actual physiological quality of the seed, as it may germinate and present no potential to emerge (HÖFS et al., 2004). In addition, because of the limitations of the germination test, especially regarding the lower sensitivity to batch differentiation, the use of vigor tests is also required. These tests seek complementary responses to those provided by the germination test with consistent information (OHLSON et al., 2010).

This study verified the physical and physiological attributes of saved cowpea seeds used in Rio Grande do Norte.

\section{MATERIAL AND METHODS}

The experiment was carried out at the Federal Rural Semi-Arid University (UFERSA), Mossoró, $\mathrm{RN}$. Thirty-nine samples of cowpea were collected in areas of the Brazilian semi-arid region: 37 of saved seeds collected at some pre-defined sites in Rio Grande do Norte, and two of certified seeds of the "BRS Pujante" and "BRS Guariba" varieties used as controls. Certified cowpea seeds were purchased from Embrapa Produtos and Mercado, Petrolina, PE.

Seeds were homogenized, packed in kraft paper bags, and kept in a controlled environment $\left(15^{\circ} \mathrm{C}\right.$ and $50 \%$ relative humidity) throughout the experimental phase. Each sample of approximately $1.5 \mathrm{~kg}$ of seeds was fractionated into working samples (400 g) using the Gamet mechanical divider, according to the Rules for Seed Analysis (BRASIL, 2009). Both the saved seeds and those produced by Embrapa Produtos and Negócios were analyzed for physical and physiological attributes.

Moisture was determined by the oven method at $105 \pm 3^{\circ} \mathrm{C}$ for 24 hours (BRASIL, 2009) by weighing two subsamples of 25 seeds. Results were expressed as percentage (wet basis).

Physical purity was tested according to the Rules for Seed Analysis (BRASIL, 2009). The working sample was fractionated and analyzed for pure seeds, other seeds, and inert material. Results were expressed as percentage of pure seeds.

The weight of 1,000 seeds was determined from eight replicates of 100 seeds for each sample obtained from the pure seed portion (BRASIL, 2009).

Hectoliter weight was determined using four replicates obtained from the average sample of each material. We used a hectoliter device with a quarter liter capacity, according to the following formula: $\mathrm{HW}=(\mathrm{WHD} \times 100) / \mathrm{DV}$, where: HW = hectoliter weight; WHD = weight obtained in the hectoliter device; and VB = device volume (BRASIL, 2009).

The germination test was performed with four subsamples of 50 seeds per sample, which were seeded in aluminum trays $(43 \mathrm{~cm}$ long, 27.5 wide, and $5 \mathrm{~cm}$ high) on washed and sterilized sand substrate. Initially, the substrate was moistened with distilled water $(60 \%$ of retention capacity). After sowing, the trays remained in the laboratory (25 to $30^{\circ} \mathrm{C}$ and $\left.70 \% \mathrm{RH}\right)$. The counts were performed on the fifth and eighth days after sowing, and the results were expressed as the percentage of normal seedlings (BRASIL, 2009).

Field emergence was tested in a bed with four replicates of 100 seeds sown in a spacing of $5 \times 5 \mathrm{~cm}$. Evaluations were completed at 12 days after sowing, and the results were expressed as the percentage of normal seedlings.

The emergence rate index was determined in combination with the field emergence test and with daily counts from emergence of the first emerged seedlings. At 12 days, the emergence rate index was calculated using the following 
formula recommended by Maguire (1962): $\mathrm{ERI}=\mathrm{E} 1 / \mathrm{N} 1+\mathrm{E} 2 / \mathrm{N} 2+\ldots \mathrm{En} / \mathrm{Nn}$, where $\mathrm{ERI}=$ emergence rate index; $\mathrm{E} 1, \mathrm{E} 2$, and $\mathrm{En}=$ number of normal seedlings computed in the first, second, and last counts, respectively; and N1, $\mathrm{N} 2$, and $\mathrm{Nn}=$ number of days since sowing in the first, second, and last counts.

To determine the shoot dry mass, seedlings were cut in the neck region on the twelfth day after sowing in field, packed in paper bags, and placed in a forced circulation air oven at $65^{\circ} \mathrm{C}$ for seven days until reaching constant weight. Mean results were expressed in grams by dividing the total weight of seedlings by the number of seedlings in the package.

To determine accelerated aging, seeds were distributed on suspended screens inside plastic boxes $(11 \times 11 \times 3.5 \mathrm{~cm})$ containing $40 \mathrm{~mL}$ of distilled water. The boxes were capped and kept in a germ chamber of biochemical oxygen demand (BOD) regulated at $42^{\circ} \mathrm{C}$ for 48 hours (DUTRA; TEÓFILO, 2007). After that period, a portion of seeds was removed to determine moisture, and then the germination test was performed as previously described, counting the normal seedlings on the fifth day after sowing (BRASIL, 2009).

Seed classification by color was not performed because the seeds used were collected in the year 2013 from small producers of Rio Grande do Norte. Most producers stored seeds from previous years as a guarantee of survival of the genetic material due to the low rainfall in the various regions of the state.

The field emergence test used a randomized block design. The other analyses used a completely randomized design. Data were submitted to analysis of variance, and means were compared by the Scott-Knott test at $5 \%$ probability using ASSISTAT 7.7 beta software (SILVA; AZEVEDO, 2009).

\section{RESULTS AND DISCUSSION}

The initial moisture of the saved cowpea seeds ranged from 9.5 to $21.3 \%$. The moisture values of the certified seeds "BRS Pujante" and "BRS Guariba" were $8.9 \%$ and $10.8 \%$, respectively (Table 1 ). The moisture values of the certified seed varieties were similar, with variation below the maximum accepted amplitude of three to four percentage points (KRZYZANOWSKI et al., 1999). In the saved seeds, variation was 12.4 percentage points, with no patterns in the different stages of management of these seeds from pre-harvest to storage. The last stage was probably the most important to this aspect, because the use of different means of packaging of the seeds was verified during collections.

More than $50 \%$ of the cowpea seed samples showed moisture content above $12 \%$, probably due to the inadequate drying process used by the producer. For Carvalho and Nakagawa (2012), values above this percentage caused intense respiration of seeds, leading to loss of vigor and eventual decreases in germination. This is evident in sample 24, which presented higher moisture $(21.3 \%)$, reflecting negatively in all physiological analyses (Tables 1 and 2).

In addition, moisture also influenced the weight of 1,000 seeds. Seeds with higher moisture content resulted in higher weight of 1,000 seeds, because seeds with high water content tend to be denser and heavier, while those with low moisture content tend to be lighter. Oliveira Neto et al. (2012) verified a similar behavior when observing that the reduction in water content of bean seeds of the Emgopa 201-Ouro cultivar reduced the mass of 1,000 seeds from $199.87 \mathrm{~g}$ to $176.89 \mathrm{~g}$.

The weight of 1,000 seeds is a measure of physical quality used for different purposes, including comparison of the quality of different batches and also the determination of crop yield. Carvalho and Nakagawa (2012) point out that larger seeds have more reserves and, consequently, are more vigorous.

The variation of the weight of 1,000 seeds among saved seeds was $193 \mathrm{~g}$, whereas variation in certified seeds was $32 \mathrm{~g}$. This variable was statistically lower for $33 \%$ of the saved seed samples than that of certified seeds (Table 1). The weight of 1,000 seeds is directly influenced by the chemical and physical properties of the soil, which can influence the growth, productivity, and yield of cowpea. According to Ndema et al. (2010), this determination can also be influenced by genetic variation between cultivars and the variation of crop sites. High temperature conditions during the reproductive period, which are common in semi-arid regions, can also lead to a reduced weight of 1,000 seeds, as verified by Hoffmann Júnior et al. (2007) for some less-tolerant genotypes.

The hectoliter weight was statistically lower than that of certified seeds in $72 \%$ of saved seed samples (Table 1). Besides genetic variability, this result may also be due to the influence of climate and soil fertility. In the last five years, Rio Grande do Norte has presented low rainfall, a characteristic inherent to semi-arid zones (NDEMA et al., 2010), and some localities have low-fertility soils. These factors probably contributed negatively to increasing this percentage. 
Table 1. Physical quality of certified cowpea seeds compared to 37 samples of saved seeds of the same species collected in the Brazilian semi-arid region.

\begin{tabular}{|c|c|c|c|c|c|c|c|}
\hline Samples & \multicolumn{2}{|c|}{$\mathrm{M}(\%)$} & \multicolumn{2}{|c|}{ HW (kg/hL) } & \multicolumn{2}{|c|}{ WTS (g) } & PP (\%) \\
\hline \multicolumn{8}{|l|}{ Certified seeds } \\
\hline "BRS Guariba" & 10.8 & $\mathrm{f}$ & 82.4 & $\mathrm{a}$ & 204 & 1 & 100 \\
\hline "BRS Pujante" & 8.9 & $\mathrm{~d}$ & 76.0 & $\mathrm{~g}$ & 236 & g & 99.8 \\
\hline$--\overline{\text { Saved seeds }}-\overline{-}$ & & & -- & & -- & & --- \\
\hline 1 & 12.5 & $\mathrm{~d}$ & 73.6 & $\mathrm{i}$ & 228 & $\mathrm{~g}$ & 99.5 \\
\hline 2 & 12.5 & $d$ & 69.6 & $\mathrm{n}$ & 267 & d & 100.0 \\
\hline 3 & 10.9 & $\mathrm{e}$ & 73.2 & $\mathrm{j}$ & 191 & $\mathrm{~m}$ & 99.0 \\
\hline 4 & 10.4 & $\mathrm{e}$ & 72.8 & $\mathrm{j}$ & 191 & $\mathrm{~m}$ & 99.8 \\
\hline 5 & 10.6 & $\mathrm{e}$ & 79.6 & d & 169 & o & 99.6 \\
\hline 6 & 12.7 & $\mathrm{~d}$ & 72.0 & 1 & 264 & $\mathrm{~d}$ & 98.8 \\
\hline 7 & 10.1 & $\mathrm{f}$ & 68.0 & o & 253 & $\mathrm{e}$ & 100.0 \\
\hline 8 & 14.3 & $\mathrm{c}$ & 78.4 & $\mathrm{e}$ & 290 & $\mathrm{c}$ & 99.6 \\
\hline 9 & 12.2 & $\mathrm{~d}$ & 76.0 & g & 159 & $\mathrm{p}$ & 100.0 \\
\hline 10 & 10.5 & $\mathrm{e}$ & 77.2 & $\mathrm{f}$ & 352 & $\mathrm{a}$ & 100.0 \\
\hline 11 & 10.3 & $\mathrm{e}$ & 72.8 & $\mathrm{j}$ & 219 & $\mathrm{~h}$ & 97.9 \\
\hline 12 & 13.0 & $\mathrm{~d}$ & 74.4 & $\mathrm{i}$ & 184 & $\mathrm{n}$ & 97.1 \\
\hline 13 & 13.7 & c & 72.0 & 1 & 191 & $\mathrm{~m}$ & 99.1 \\
\hline 14 & 16.7 & $\mathrm{~b}$ & 72.0 & 1 & 263 & $\mathrm{~d}$ & 98.8 \\
\hline 15 & 11.2 & $\mathrm{e}$ & 73.6 & $\mathrm{i}$ & 233 & g & 99.8 \\
\hline 16 & 12.3 & $d$ & 72.8 & $\mathrm{j}$ & 180 & $\mathrm{n}$ & 99.7 \\
\hline 17 & 12.0 & $\mathrm{~d}$ & 74.0 & $\mathrm{i}$ & 282 & $\mathrm{c}$ & 99.9 \\
\hline 18 & 12.7 & $\mathrm{~d}$ & 76.8 & $\mathrm{f}$ & 177 & $\mathrm{n}$ & 98.3 \\
\hline 19 & 9.9 & $\mathrm{f}$ & 69.6 & $\mathrm{n}$ & 240 & $\mathrm{f}$ & 98.3 \\
\hline 20 & 15.7 & $\mathrm{~b}$ & 78.0 & e & 168 & o & 99.9 \\
\hline 21 & 10.3 & $\mathrm{e}$ & 70.0 & $\mathrm{n}$ & 195 & $\mathrm{~m}$ & 100.0 \\
\hline 22 & 10.7 & $\mathrm{e}$ & 77.2 & $\mathrm{f}$ & 219 & $\mathrm{~h}$ & 99.9 \\
\hline 23 & 11.1 & $\mathrm{e}$ & 72.4 & 1 & 207 & $\mathrm{j}$ & 99.3 \\
\hline 24 & 21.3 & $\mathrm{a}$ & 72.4 & 1 & 235 & g & 100.0 \\
\hline 25 & 15.0 & $\mathrm{~b}$ & 76.0 & g & 237 & g & 98.0 \\
\hline 26 & 12.9 & $\mathrm{~d}$ & 82.0 & $\mathrm{~b}$ & 201 & 1 & 98.8 \\
\hline 27 & 9.5 & $\mathrm{f}$ & 65.2 & $q$ & 245 & $\mathrm{f}$ & 99.5 \\
\hline 28 & 11.4 & $d$ & 73.6 & $\mathrm{i}$ & 203 & 1 & 98.0 \\
\hline 29 & 11.4 & $\mathrm{~d}$ & 66.0 & $\mathrm{p}$ & 289 & $\mathrm{c}$ & 99.9 \\
\hline 30 & 14.5 & $\mathrm{c}$ & 73.2 & $\mathrm{j}$ & 302 & $\mathrm{~b}$ & 100.0 \\
\hline 31 & 12.9 & $\mathrm{~d}$ & 73.2 & $\mathrm{j}$ & 212 & i & 98.9 \\
\hline 32 & 12.0 & $\mathrm{~d}$ & 80.4 & $\mathrm{c}$ & 221 & $\mathrm{~h}$ & 98.8 \\
\hline 33 & 11.6 & $\mathrm{~d}$ & 75.2 & $\mathrm{~h}$ & 213 & $\mathrm{i}$ & 99.9 \\
\hline 34 & 10.9 & $\mathrm{e}$ & 70.8 & $\mathrm{~m}$ & 256 & $\mathrm{e}$ & 99.9 \\
\hline 35 & 12.0 & d & 73.2 & $\mathrm{j}$ & 207 & $\mathrm{j}$ & 99.8 \\
\hline 36 & 11.4 & $\mathrm{~d}$ & 76.0 & g & 184 & $\mathrm{n}$ & 99.9 \\
\hline 37 & 10.6 & $\mathrm{e}$ & 66.4 & $\mathrm{p}$ & 250 & $\mathrm{e}$ & 99.5 \\
\hline C.V. (\%) & 4.64 & & 0.2 & & 3.78 & & - \\
\hline
\end{tabular}

Means followed by the same letter in the column do not differ statistically by the Scott-Knott test at $5 \%$ probability. $\mathrm{M}=$ moisture $(\%)$; $\mathrm{HW}=$ hectoliter weight $(\mathrm{kg} / \mathrm{hL})$; WTS $=$ Weight of one thousand seeds (g); PP = Physical purity (\%). 
According to current legislation, the minimum acceptable value of physical purity for classification in any category of cowpea seed is $98 \%$ (BRASIL, 2013). Physical purity ranged from 97.1 to $100 \%$ in the seed samples analyzed, and only $5 \%$ of these samples presented values lower than those recommended for commercialization (Table 1). Straw, pods, and clods were found in these samples, which show that the beneficiation stage was not efficient. Mertz et al. (2007) obtained purity of 97 to $99 \%$ when evaluating the physical quality of cowpea genotypes, corroborating the findings of our study.

The germination test often does not accurately differentiate quality among several samples, because it is performed under controlled conditions. However, we found that this test and the first germination count test were able to stratify samples into seven and six quality levels, respectively. The field emergence test was able to differentiate seed samples into only three classes (Table 2). Coelho et al. (2010), comparing cultivars of common beans, also obtained greater differentiation in the quality of samples in the germination test (six classes). In the field emergence test, three classes were established.

Comparing seeds, $82 \%$ of the saved seeds had lower germination than the certified seeds. For the first germination count, $87 \%$ of the saved seeds also had lower values than the certified seeds (Table 2).

As previously mentioned, the field emergence test did not satisfactorily express differences between samples. The emergence rate index test in the field was more sensitive (Table 2). This finding is in agreement with Marcarello et al. (2012), who verified similar germination and emergence values in cowpea cultivars. According to those authors, this occurrence often shows differences in germination and emergence rates, characterizing differences in vigor between samples. The field emergence and emergence speed index indicated that $41-72 \%$ of saved seed samples were statistically lower than certified seed samples.

Concerning shoot dry matter, there was accumulation of phytomass of 4.7 to $15.5 \mathrm{~g}$ between saved seeds. The certified "BRS Guariba" and "BRS Pujante" seeds were statistically superior to $84 \%$ of the saved seeds. This test ranked seed samples at five different levels of vigor. According to Mondo et al. (2012), plants originating from seeds with high physiological potential present greater efficiency in dry mass production. For Nakagawa (1999), vigorous seeds provide greater transfer of dry mass of their reserve tissues to the embryonic axis in the germination phase, producing seedlings with greater mass due to the greater accumulation of matter. Among saved seeds, $8 \%$ were superior to the "BRS Guariba" and "BRS Pujante" controls. This likely occurred due to some materials presenting high genetic variability and adaptation to rustic cultivation environments, such as high temperatures, water deficiency, soil nutrient shortage, excess acidity, or alkalinity (PATERNIANI et al., 2000).

The accelerated aging test showed that $92 \%$ of saved seed samples had lower values than certified seeds. This test, similar to the germination test, showed great sensitivity in the differentiation of samples, also stratifying them in seven levels of quality. Thus, we detected more subtle differences, which are undetected in field emergence, identifying those samples that already showed decrease in vigor. Using the same test, Dutra and Teófilo (2007) detected more evident separation of different levels of vigor and viability in cowpea seeds.

Analyzing the physical and physiological variables tested, we verified the superiority of the cultivars "BRS Guariba" and "BRS Pujante" in relation to saved seeds in the state of Rio Grande do Norte. Among the reasons for the superior quality of certified seeds are the certified origin and guarantee of genetic and varietal purity, as these seeds originated from controlled and supervised production processes. On the other hand, one of the factors minimizing the quality of saved seeds was irregular rainfall in the state.

In general, tests pointed out differences in quality among saved seeds. Some samples stood out with characteristics compatible with those of certified seeds, such as samples 4 and 6 . On the other hand, sample 24 was indicated as the most inferior (Table 2). This suggests both the existence of high genetic variability and the influence of crop environment according to genotype. Thus, some genotypes of cowpea and common bean (Phaseolus vulgaris) stand out in a given environment due to their territorialities, as verified by Dutra et al. (2007) and Coelho et al. (2010). 
Table 2. Physiological quality of certified cowpea seeds compared to 37 samples of saved seeds of the same species collected in the Brazilian semi-arid region.

\begin{tabular}{|c|c|c|c|c|c|c|c|c|c|c|c|c|c|}
\hline $\begin{array}{l}\text { Samples } \\
\text { Certified seeds }\end{array}$ & \multicolumn{2}{|c|}{$\begin{array}{c}\mathrm{G} \\
(\%)\end{array}$} & \multicolumn{2}{|c|}{$\begin{array}{c}\text { FGC } \\
(\%)\end{array}$} & \multicolumn{2}{|c|}{$\begin{array}{l}\mathrm{FE} \\
(\%)\end{array}$} & \multicolumn{2}{|c|}{ ERI } & \multicolumn{2}{|c|}{$\begin{array}{c}\text { SDM } \\
(\mathrm{g})\end{array}$} & \multicolumn{2}{|c|}{$\begin{array}{l}\text { AA } \\
(\%)\end{array}$} & $\begin{array}{c}\text { M/AA } \\
(\%)\end{array}$ \\
\hline "BRS Guariba" & 98 & $\mathrm{a}$ & 97 & $\mathrm{a}$ & 94 & $\mathrm{a}$ & 15.9 & $\mathrm{a}$ & 13.4 & $\mathrm{~b}$ & 92 & $\mathrm{a}$ & 22.5 \\
\hline “BRS Pujante” & 99 & $\mathrm{a}$ & 97 & $\mathrm{a}$ & 98 & $\mathrm{a}$ & 15.4 & $\mathrm{a}$ & 13.8 & $\mathrm{~b}$ & 93 & a & 24.3 \\
\hline$-\overline{\text { Saved seeds }}-$ & & & & & & & & & & & --- & & --- \\
\hline 1 & 82 & $\mathrm{~d}$ & 81 & $\mathrm{c}$ & 93 & $\mathrm{a}$ & 15.2 & $\mathrm{a}$ & 11.8 & $\mathrm{c}$ & 85 & $\mathrm{~b}$ & 25.3 \\
\hline 2 & 95 & $\mathrm{~b}$ & 90 & b & 92 & $\mathrm{a}$ & 15.4 & $\mathrm{a}$ & 12 & $\mathrm{c}$ & 87 & $\mathrm{~b}$ & 22.1 \\
\hline 3 & 93 & $\mathrm{~b}$ & 92 & $\mathrm{~b}$ & 94 & $\mathrm{a}$ & 15.8 & $\mathrm{a}$ & 10.7 & d & 84 & $\mathrm{~b}$ & 29.2 \\
\hline 4 & 97 & $\mathrm{a}$ & 94 & $\mathrm{a}$ & 97 & $\mathrm{a}$ & 16.3 & $\mathrm{a}$ & 11.8 & $\mathrm{c}$ & 95 & $\mathrm{a}$ & 23.2 \\
\hline 5 & 95 & $\mathrm{~b}$ & 88 & $\mathrm{~b}$ & 94 & $\mathrm{a}$ & 15.1 & a & 8.7 & $\mathrm{e}$ & 95 & a & 23.1 \\
\hline 6 & 97 & a & 95 & $\mathrm{a}$ & 82 & $\mathrm{~b}$ & 16 & a & 14.8 & $\mathrm{a}$ & 84 & $\mathrm{~b}$ & 22.9 \\
\hline 7 & 93 & $\mathrm{~b}$ & 92 & $\mathrm{~b}$ & 93 & $\mathrm{a}$ & 14.9 & b & 12 & $\mathrm{c}$ & 83 & $\mathrm{~b}$ & 24.1 \\
\hline 8 & 88 & $\mathrm{c}$ & 83 & $\mathrm{c}$ & 92 & $\mathrm{a}$ & 15 & $\mathrm{a}$ & 13.5 & $\mathrm{~b}$ & 86 & b & 16.9 \\
\hline 9 & 92 & $\mathrm{c}$ & 90 & b & 76 & $\mathrm{~b}$ & 12.8 & $\mathrm{c}$ & 8.5 & $\mathrm{e}$ & 73 & $d$ & 24.9 \\
\hline 10 & 94 & $\mathrm{~b}$ & 95 & $\mathrm{a}$ & 83 & $\mathrm{~b}$ & 13.9 & $b$ & 15.4 & $\mathrm{a}$ & 89 & b & 20.8 \\
\hline 11 & 89 & $\mathrm{c}$ & 84 & $\mathrm{c}$ & 93 & $\mathrm{a}$ & 14.8 & b & 11.9 & $\mathrm{c}$ & 85 & b & 24.7 \\
\hline 12 & 98 & $\mathrm{a}$ & 96 & $\mathrm{a}$ & 85 & $\mathrm{~b}$ & 14.2 & $\mathrm{~b}$ & 9.7 & d & 84 & b & 25.2 \\
\hline 13 & 90 & $\mathrm{c}$ & 87 & $\mathrm{c}$ & 84 & $\mathrm{~b}$ & 14.6 & $\mathrm{~b}$ & 9.9 & d & 86 & b & 26.9 \\
\hline 14 & 96 & $\mathrm{~b}$ & 84 & $\mathrm{c}$ & 88 & $\mathrm{a}$ & 14.5 & $\mathrm{~b}$ & 13 & $\mathrm{c}$ & 97 & a & 18.9 \\
\hline 15 & 73 & $\mathrm{f}$ & 60 & e & 77 & $\mathrm{~b}$ & 11.2 & $\mathrm{c}$ & 8.4 & e & 6 & $\mathrm{~g}$ & 25.3 \\
\hline 16 & 85 & d & 84 & $\mathrm{c}$ & 92 & $\mathrm{a}$ & 14.6 & $\mathrm{~b}$ & 8.3 & $\mathrm{e}$ & 71 & $\mathrm{~d}$ & 29 \\
\hline 17 & 85 & d & 79 & $d$ & 89 & $\mathrm{a}$ & 14.6 & b & 13.3 & b & 78 & $\mathrm{c}$ & 17.7 \\
\hline 18 & 88 & $\mathrm{c}$ & 84 & $\mathrm{c}$ & 80 & $\mathrm{~b}$ & 13.5 & $\mathrm{~b}$ & 7.8 & $\mathrm{e}$ & 37 & $\mathrm{e}$ & 22.5 \\
\hline 19 & 90 & $\mathrm{c}$ & 81 & $\mathrm{c}$ & 94 & $\mathrm{a}$ & 15.5 & $\mathrm{a}$ & 13 & $\mathrm{c}$ & 81 & $\mathrm{c}$ & 21.3 \\
\hline 20 & 98 & $\mathrm{a}$ & 97 & $\mathrm{a}$ & 90 & $\mathrm{a}$ & 15 & $\mathrm{a}$ & 8.5 & $\mathrm{e}$ & 78 & $\mathrm{c}$ & 28.5 \\
\hline 21 & 89 & $\mathrm{c}$ & 86 & $\mathrm{c}$ & 90 & $\mathrm{a}$ & 14.7 & $\mathrm{~b}$ & 10.1 & d & 76 & $\mathrm{c}$ & 28.5 \\
\hline 22 & 72 & $\mathrm{f}$ & 74 & d & 89 & $\mathrm{a}$ & 14.7 & $\mathrm{~b}$ & 10.1 & d & 84 & $b$ & 23.5 \\
\hline 23 & 75 & $\mathrm{f}$ & 74 & d & 82 & $\mathrm{~b}$ & 13.5 & $\mathrm{~b}$ & 10.9 & d & 78 & $\mathrm{c}$ & 22.9 \\
\hline 24 & 39 & g & 28 & $\mathrm{f}$ & 43 & $\mathrm{c}$ & 7.5 & d & 4.7 & $\mathrm{f}$ & 15 & $\mathrm{f}$ & 25.2 \\
\hline 25 & 73 & $\mathrm{f}$ & 60 & e & 75 & $b$ & 12.2 & $\mathrm{c}$ & 9.1 & d & 68 & $\mathrm{~d}$ & 19.1 \\
\hline 26 & 82 & $\mathrm{~d}$ & 77 & $d$ & 86 & $\mathrm{~b}$ & 14.4 & b & 10.1 & d & 79 & $\mathrm{c}$ & 27.5 \\
\hline 27 & 79 & e & 77 & $d$ & 85 & $\mathrm{~b}$ & 13.9 & b & 11.5 & $\mathrm{c}$ & 72 & d & 24.7 \\
\hline 28 & 90 & $\mathrm{c}$ & 79 & $d$ & 92 & $\mathrm{a}$ & 13.9 & $\mathrm{~b}$ & 10.5 & d & 69 & $d$ & 22.3 \\
\hline 29 & 95 & $\mathrm{~b}$ & 90 & b & 90 & $\mathrm{a}$ & 14.2 & $\mathrm{~b}$ & 15.5 & $\mathrm{a}$ & 78 & $\mathrm{c}$ & 17.5 \\
\hline 30 & 89 & $\mathrm{c}$ & 88 & $\mathrm{~b}$ & 74 & $\mathrm{~b}$ & 12 & $\mathrm{c}$ & 10 & d & 75 & $\mathrm{c}$ & 17.2 \\
\hline 31 & 92 & $\mathrm{c}$ & 91 & $\mathrm{~b}$ & 82 & $\mathrm{~b}$ & 13.7 & $\mathrm{~b}$ & 8.5 & e & 70 & d & 23.8 \\
\hline 32 & 94 & $\mathrm{~b}$ & 89 & $\mathrm{~b}$ & 91 & $\mathrm{a}$ & 15.6 & $\mathrm{a}$ & 13 & $\mathrm{c}$ & 87 & $\mathrm{~b}$ & 21.6 \\
\hline 33 & 96 & $\mathrm{~b}$ & 97 & a & 87 & $\mathrm{a}$ & 14.7 & $b$ & 10.8 & d & 77 & $\mathrm{c}$ & 25.7 \\
\hline 34 & 89 & $\mathrm{c}$ & 89 & b & 92 & $\mathrm{a}$ & 15.1 & $\mathrm{a}$ & 13.8 & b & 79 & $\mathrm{c}$ & 22.5 \\
\hline 35 & 90 & $\mathrm{c}$ & 85 & $\mathrm{c}$ & 84 & $\mathrm{~b}$ & 13.9 & $\mathrm{~b}$ & 9.6 & d & 69 & d & 9.9 \\
\hline 36 & 95 & $\mathrm{~b}$ & 91 & b & 89 & $\mathrm{a}$ & 13.7 & $\mathrm{~b}$ & 9.3 & d & 40 & $\mathrm{e}$ & 25.3 \\
\hline 37 & 97 & $\mathrm{a}$ & 92 & $\mathrm{~b}$ & 93 & $\mathrm{a}$ & 14.4 & $\mathrm{~b}$ & 11.9 & $\mathrm{c}$ & 81 & $\mathrm{c}$ & 18.7 \\
\hline C.V. $(\%)$ & 3.2 & & 4. & & 0 & & 6.73 & & & & 6.3 & & \\
\hline
\end{tabular}

Means followed by the same letters in the columns do not differ statistically by the Scott-Knott test at $5 \%$ probability. $\mathrm{G}=$ germination test; $\mathrm{FGC}=$ first germination count; $\mathrm{FE}=$ field emergence; $\mathrm{ERI}=$ emergence rate index; $\mathrm{SDM}=$ shoot dry matter; $\mathrm{AA}=$ accelerated aging; $\mathrm{M} / \mathrm{AA}=$ moisture after accelerated aging. 


\section{CONCLUSION}

The use of saved cowpea seeds by small farmers in the semi-arid areas of Northeastern Brazil is impractical, because these seeds have inferior physical and physiological qualities compared to certified cowpea seeds.

\section{REFERENCES}

BERTINI, C. H. C. M. et al. Análise multivariada e índice de seleção na identificação de genótipos superiores de feijão-caupi. Acta Scientiarum. Agronomy, v. 32, n. 4, p. 613-619, 2010.

BRASIL. Ministério da Agricultura, Pecuária e Abastecimento. Instrução normativa $n^{0} \mathbf{4 5}$, de 17 de setembro de 2013. Diário Oficial da União, Brasília, DF, 18 set. 2013, Seção I, p. 14. Disponível em: <http://www.jusbrasil.com.br/diarios/59354731/ dou-secao-1-20-09-2013-pg-13>. Acesso em: 21 de nov. de 2017.

BRASIL. Ministério da Agricultura, Pecuária e Abastecimento. Regras para análise de sementes. Ministério da Agricultura, Pecuária e Abastecimento. Secretaria de Defesa Agropecuária. Brasília, Mapa/ ACS, 2009. 395 p.

CARVAlHO, N. M.; NAKAGAWA, J. Sementes: ciência, tecnologia e produção. 5. ed. Jaboticabal, SP: Funep, 2012. 590 p.

COELHO, M. M. C. et al. Potencial fisiológico em sementes de cultivares de feijão crioulo (Phaseolus vulgaris L.). Revista Brasileira de Sementes, Londrina, v. 32, n. 3, p. 97-105, 2010.

DUTRA, A. S. et al. Qualidade fisiológica de sementes de feijão caupi em quatro regiões do estado do Ceará. Revista Brasileira de Sementes, Londrina, v. 29, n. 1, p. 111-116, 2007.

DUTRA, A. S.; TEÓFILO, E. M. Envelhecimento acelerado para avaliar o vigor de sementes de feijão caupi. Revista Brasileira de Sementes, v. 29, n. 1, p. 193-197, 2007.

DUTRA, K. A. et al. Control of Callosobruchus maculatus (FABR.) (Coleoptera: Chrysomelidae: Bruchinae) in Vigna unguiculata (L.) WALP. with essential oils from four Citrus spp. plants. Journal of Stored Products Research, v. 68, s/n., p. 25-32, 2016.

HOFFMANN JÚNIOR, L. et al. Resposta de cultivares de feijão à alta temperatura do ar no período reprodutivo. Ciência Rural, v. 37, n. 6, p.
1543-1548, 2007.

HÖFS, A. et al. Emergência e crescimento de plântulas de arroz em resposta à qualidade fisiológica de sementes. Revista Brasileira de Sementes, v. 26, n. 1, p. 92-97, 2004.

KRZYZANOWSKI, F. C. et al. Vigor de sementes: conceitos e testes. Londrina, PR: ABRATES, 1999. $218 \mathrm{p}$.

LEITE, L. F. C. et al. Nodulação e produtividade de grãos do feijão-caupi em resposta ao molibdênio. Revista Ciência Agronômica, v. 40, n. 4, p. $492-$ 497, 2009

LOBO JÚNIOR, M. et al. Testes para avaliação da qualidade de sementes de feijão comum. Santo Antônio de Goiás-GO: Embrapa Arroz e Feijão, 2013. 4 p. (Circular Técnica, 90). Disponível em: $<$ http://www.infoteca.cnptia.embrapa.br/bitstream/ doc/970251/1/circulartecnica90.pdf $>$. Acesso em: 21 de nov. 2017.

MAGUIRE, J. D. Speed of germination: aid in selection and evaluation for seedling emergence and vigour. Crop Science, v. 2, n. 2, p. 176-177, 1962.

MARCARELLO, A. et al. Qualidade fisiológica de sementes de feijoeiro em função da aplicação foliar de cobalto e molibdênio. Global Science Technology, v. 5, n. 2, p. 121-132, 2012.

MARCOS-FILHO, J.; NOVEMBRE, A. D. L. C. Avaliação do potencial fisiológico de sementes de hortaliças. In: NASCIMENTO, W. M. (Ed.). Tecnologia de sementes de hortaliças. Brasília: Embrapa Hortaliças, 2009. p. 185-243.

MERTZ, L. M. et al. Qualidade fisiológica e sanitária de sementes de feijão-miúdo beneficiadas em mesa gravitacional. Revista Brasileira de Sementes, v. 29, n. 3, p. 1-8, 2007.

MONDO, V. H. V. et al. Vigor de sementes e desempenho de plantas de milho. Revista Brasileira de Sementes, v. 34, n. 1 p. 143-155, 2012.

NAKAGAWA, J. Testes de vigor baseados no desempenho de plântulas. In: KRZYZANOWSKI, F. C.; VIEIRA, R. D.; FRANÇA-NETO, J. B. (Eds.). Vigor de sementes: conceitos e testes. Londrina: ABRATES, 1999. cap. 1, p. 1-21.

NDEMA, N. E. et al. Effects of some physical and chemical characteristics of soil on productivity and yield of cowpea (Vigna unguiculata L. Walp.) in coastal region (Cameroon). African Journal of Environmental Science and Technology, v. 4, n. 3, p. 108-114, 2010. 
OHLSON, O. D. C. et al. Teste de envelhecimento acelerado em sementes de trigo. Revista Brasileira de Sementes, v. 32, n. 4, p. 118-124, 2010.

OLIVEIRA NETO, M. C. et al. Propriedades físicas de sementes de feijão (Phaseolus vulgaris L.) variedade "Emgopa 201-Ouro". Revista Agrotecnologia, v. 1, n. 1, p. 99-110, 2012.

PATERNIANI, E. et al. O valor dos recursos genéticos de milho para o Brasil: uma abordagem histórica da utilização do germoplasma. In: UDRY, C. W.; DUARTE, W. (Eds.). Uma história brasileira do milho: o valor dos recursos genéticos. Brasília: Paralelo 15, 2000. cap. 1, p. 11-41.

SANTOS, J. A. D. S. et al. Desempenho agronômico e divergência genética entre genótipos de feijãocaupi cultivados no ecótono Cerrado/Pantanal. Bragantia, v. 73, n. 4, p. 377-382, 2014.

SILVA, F. A. S.; AZEVEDO, C. A. V. Principal components analysis in the software Assistat Statistical Assistance. In: World Congress on Computers in Agriculture, 7, 2009, Reno. Proceedings... St. Joseph: ASABE, 2009. p. 1-5. 